\title{
An assessment of the availability of cavities for secondary cavity- nesting birds in certified and conventionally-logged Neotropical rainforests
}

\author{
Alejandro A Schaaf ${ }^{(1)}$, \\ Ever Tallei ${ }^{(1-2)}$, \\ Román A Ruggera ${ }^{(1-2)}$, \\ Constanza G Vivanco ${ }^{(1-2)}$, \\ Luis Rivera ${ }^{(1-2)}$, \\ Natalia Politi ${ }^{(1-2)}$
}

\begin{abstract}
The high level of forest intervention and the decrease in biodiversity as a result of logging are incentives to implement forest certification schemes. Despite the advances in the results of the impact of forest certification on biodiversity, there are few studies on species with specific habits, such as cavitynesting birds. The objective of this study is to compare the impact of forest certification and conventional logging on the richness, availability (density) and dominance of potentially suitable cavity trees for secondary cavity-nesting birds in the subtropical forests of northwestern Argentina. Seven sites were selected: three control sites which were not logged for at least 40 years, one site under Forest Stewardship Council (FSC) certification, and three sites with conventional logging. The results suggest that logged forests under FSC-certification may guarantee a diversity, availability (density) and dominance of potentially suitable cavity trees for secondary cavity-nesting birds, as well as certain characteristics (such as DBH $>40 \mathrm{~cm}$ ), similar to unlogged forests for this group of birds. Therefore, we suggest that the forests of northwestern Argentina should be managed by a scheme under forest certification so that the high levels of cavity tree species are maintained.
\end{abstract}

Keywords: Argentina, Birds, Cavity Trees, Certification Forest, Forest Stewardship Council, South-America, Subtropical Forests tions were very successful in raising awaresocial, economic, and environmental importance of forests (Rametsteiner \& Simula 2003, Elbakidze et al. 2011). With regards to the environment, it was shown that certifications (e.g., FSC, Forest Stewardship Council; PEFC, Programme for the Endorsement of Forest Certification) can be effective tools for the conservation of forest biodiversity, based on measures such as reduced logging, retention of key tree species, protection of threatened species and reforestation (Ranius \& Kindvall 2004, Newsom et al. 2005, Cubbage et al. 2010, Johansson et al. 2013). Particularly, the FSC is one of the most well-known certificaness and spreading knowledge about the

(1) Instituto de Ecorregiones Andinas (INECOA), Universidad Nacional de Jujuy - Consejo Nacional de Investigaciones Científicas y Técnicas (CONICET), Av. Bolivia 1239, 4600 San Salvador de Jujuy, Jujuy (Argentina); (2) Fundación CEBio, Roca 44, 4600 San Salvador de Jujuy, Jujuy (Argentina)

@ Alejandro A Schaaf (schaaf.alejandro@gmail.com)

Received: Aug 26, 2019 - Accepted: May 21, 2020

Citation: Schaaf AA, Tallei E, Ruggera RA, Vivanco CG, Rivera L, Politi N (2020). An assessment of the availability of cavities for secondary cavity-nesting birds in certified and conventionally-logged Neotropical rainforests. iForest 13: 318-322. - doi: 10.3832/ifor3220013 [online 2020-07-28]

Communicated by: Anna Loy tions worldwide and focuses on the output of forest products, taking into account the economic, social, and environmental components (FSC 2015). Specifically, the environmental component of the FSC certification promotes environmentally responsible logging, selective logging with reduced impact logging (e.g., high-value tree species), waste reduction and hunting restrictions (Nebel et al. 2005, De Lima et al. 2008, FSC 2015, Miteva et al. 2015). However, many of these results come from temperate forests and little is known about the potential importance and effectiveness of certification in tropical and subtropical forests (Rametsteiner \& Simula 2003, Campos-Cerqueira et al. 2019). Furthermore, in many cases, the assessment and monitoring of forest biodiversity do not consider guidelines for animal species with specific life-history traits (Gullison 2003, Johansson et al. 2013, Arbainsyah et al. 2014), such as cavity-nesting birds.

Cavity-nesting birds require trees with specific characteristics (e.g., species, size, trees available) and these tree species are generally the most logged by forestry companies (Martin \& Eadie 1999, Cockle et al. 2010, Politi et al. 2010, Ruggera et al. 2016, Schaaf et al. 2019). Relatively few studies certification on the availability of cavities for secondary cavity-nesting birds (Zawadzka et al. 2016). Thus, the objective of this study is to compare the impact of forest assessed the impact of forest management 
management under certification with unlogged forest sites and conventional logging on cavity availability for secondary cavity-nesting birds, in a subtropical forest of northwestern Argentina. Richness, availability (density), dominance and characteristics (such as DBH, cavity entrance area) of cavity tree species in unlogged, certified and conventionally logged forests are also analysed. We expect that certified sites have less availability of cavities than unlogged sites but higher than sites with conventional logging. In addition, we expect that sites under certification have a diversity of cavity trees similar to that of unlogged sites, since tree species are conserved due to the reduction of environmental impacts (reduced impact logging).

\section{Methodology}

\section{Study area}

This study was conducted in the subtropical piedmont forests of northwestern Argentina and they are part of the seasonal dry forests of South America (Prado 2000). The climate in this area is highly seasonal, with a rainfall between 800 and $1000 \mathrm{~mm}$, concentrated in the austral summer (November to February). These forests are located at altitudes ranging between 400 and $900 \mathrm{~m}$ a.s.l. (Arias \& Bianchi 1996). The dominant tree species are Calycophyllum multiflorum, Phyllostylon rhamnoides, Anadenanthera colubrina, Myroxylon peruiferum and Myracrodruon urundeuva (Brown et al. 2001, Brown \& Malizia 2004).

\section{Fieldwork and data analyses}

Field sampling was conducted from 2014 to 2016 at seven sites located in Salta and Jujuy provinces: three sites without logging activity for at least 45 years (control sites), one site under FSC certification and three sites with conventional logging (Fig. 1). Nowadays, FSC regulations for sustainable forest management include protection of the ecosystem (e.g., bodies of water, riparian zones), environmental impact assessment and protection of endangered species and their habitats. In our study site, FSC certification implied very rigorous actions, such as the retention of some tree species with highly-valued timber to guarantee the regeneration of these tree species within the forest, the use of reduced impact logging, and the protection of threatened tree species (data provided by site owners).

At each site, an area of 100 ha was marked for sampling. Within these areas, 10 to 20 plots of 0.25 ha were defined (see Tab. S1 in Supplementary material). In each plot, cavities with an entrance of $>5 \mathrm{~cm}$ diameter and up to $16.8 \mathrm{~m}$ height were inspected using a mini-camera system attached to an extendable pole (Richardson et al. 1999). Cavity trees were identified to species level, but standing dead trees were grouped into the single category, called "snags". Cavity tree richness was determined as the mean number of tree species with at least one cavity which can be potentially used, per plot. It was estimated taking into account our knowledge of the

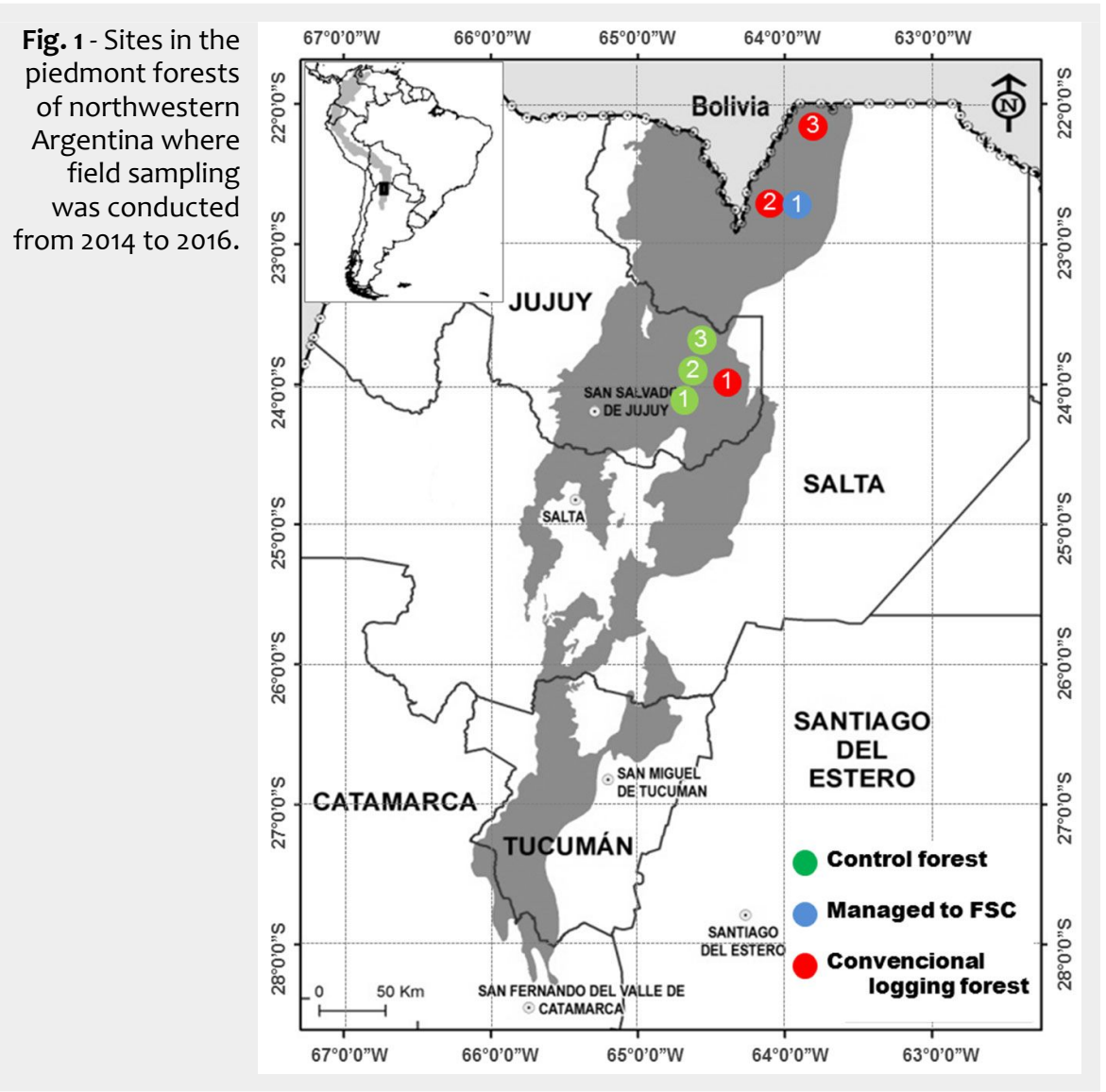

potential use of cavities suitable for secondary cavity-nesting birds. We considered a cavity to be potentially suitable if it had a hollow chamber surrounded by sound wood, accessed by a cavity entrance with a floor to support an incubation chamber, and a roof to provide overhead protection (classification based on prior knowledge of the cavities used by the species of birds, Politi et al. 2009, 2010). Similarly, we also calculated the cavities and the total cavity trees per plot (Density ha-1). The density (availability) of each cavity tree species was calculated per site and then classified into: $<1$ cavity tree ha ${ }^{-1}, 1-3$ cavity trees ha-1 and $>3$ cavity trees ha ${ }^{-1}$ (Schaaf et al. 2019). In addition, the following variables were measured for cavity trees registered in each plot: cavity type (cavities resulting from decay-formed or excavated by woodpeckers), DBH (diameter at breast height), cavity and tree height; cavity location (i.e., main trunk, primary branch, secondary branch, and tertiary branch), cavity entrance area (by measuring the horizontal and vertical diameters of the entrance, and estimated using the formula of an ellipse); and cavity internal depth (Politi et al. 2009, 2010, Ruggera et al. 2016, Schaaf et al. 2019). The differences among measured variables were compared between the sites with Kruskal-Wallis tests $(\mathrm{H})$, and using the InfoStat software (Di Rienzo et al. 2008).

Finally, we evaluated the dominance of cavity tree species in each site, according to their proportional presence $(w)$ and proportional abundance (Ap) per plot of cavity tree species: $(w)$ is the proportion of sites where a given tree species was present and (Ap) is the proportion of individuals recorded for each species per site. From this analysis, cavity tree species were categorized in four groups: Dominant, Subdominant, Common, and rare species (see details in Pinzón \& Spence 2010).

\section{Results}

In control sites, a total of 23 cavity tree species were registered in the three sites, whereas 20 cavity tree species were registered in the FSC certified site, and 17 cavity tree species in sites with conventional logging $\left(\right.$ Site $_{1}=15$, Site $_{2}=15$, and Site ${ }_{3}=14$ cavity tree species - Fig. S1 in Supplementary material). Cavity density $(\mathrm{H}=52.21, P<0.001)$, and cavity tree density $(\mathrm{H}=46.71, \mathrm{P}<0.001)$ were significantly higher in control and certified sites than in conventionally logged sites. Decay-formed cavity density ( $\mathrm{H}=$ $47.78, P<0.001)$ was significantly higher in control sites than in certified and conventionally logged sites. There were not significant differences in density of excavated cavities between sites $(\mathrm{H}=2.32, \mathrm{P}=0.567)$ (Fig. 2, Tab. S1). The DBH, and internal cavity depth did not show significant differences between control and FSC certified sites, but they were significantly higher than in conventionally logged sites $(\mathrm{H}=$ 30.32, $P<0.001$ - Fig. 3). Cavity height did 
not show significant differences between sites ( $H=9.97, P=0.125)$ (Fig. 3, Tab. S1).

Cavity tree species richness per plot was significantly higher in control and certified sites than in conventionally logged sites $(\mathrm{H}$ $=53.43, P<0.0001-$ Fig. $4 a)$. The cavity tree species with the highest density in control and FCS certified sites were $C$. multiflorum (1-3 and $>3$ tree ha ${ }^{-1}$ ) and $P$. rhamnoides (1-3 and $>3$ tree $\left.\mathrm{ha}^{-1}\right)$. In conventionally logged sites, we recorded different densities of cavity tree species (Fig. 4b). In all sites, there was a relatively large proportion of rare cavity tree species, whereas few of these species were Dominant, sub-Dominant and Common. It should be noted that snags are Common species in one control site (Fig. 4b, Fig. S1).

\section{Discussion}

The results of our study suggest that management under certification might guarantee richness, availability (density) and certain characteristics (such as DBH) of tree cavities similar to the control forests for secondary cavity-nesting birds. This may show that in these subtropical forests FSC-certified sites can maintain tree levels and characteristics suitable for secondary cavity-nesting birds. This fact is important, since many bird species of this group depend on large trees (Schaaf et al. 2019), which are reduced or absent in sites without forest certification. The low density of cavity tree species, as well as the changes in their characteristics, at sites under conventional logging, might be due to the selective logging of tree species without management plans which include sustainability criteria (Politi et al. 2010). Other studies in Neotropical rainforests showed that conventional logging can significantly reduce the availability of cavity trees (Cockle et al. 2008, Cornelius et al. 2008, Politi et al. 2009, 2010).

The results of dominance of cavity tree species were similar in control and certified sites, with the exception of A. colubrina, which is present as a dominant cavity tree species at certified sites. This particular tree species is a pioneer in sites under forest exploitation in piedmont forests (Politi et al. 2010, SGAJ 2012) and this may be the reason why it is dominant in sites under this type of certification, as well as in sites of conventionally logged forests. The absence of certain cavity tree species (such as $A$. cearensis and $M$. peruiferum), as well as the decrease in their abundance in conventionally logged sites, may be due to the way in which logging was carried out (Politi et al. 2010, SGAJ 2012). Structural characteristics and dominance of tree species varied significantly and such differences between the forest logging types may reflect factors associated with tree species (Pinzón \& Spence 2010), such as the DBH or cavity entrance area. Therefore, management strategies for subtropical forest should aim at maintaining a heterogeneous mix of tree species which provide habitat
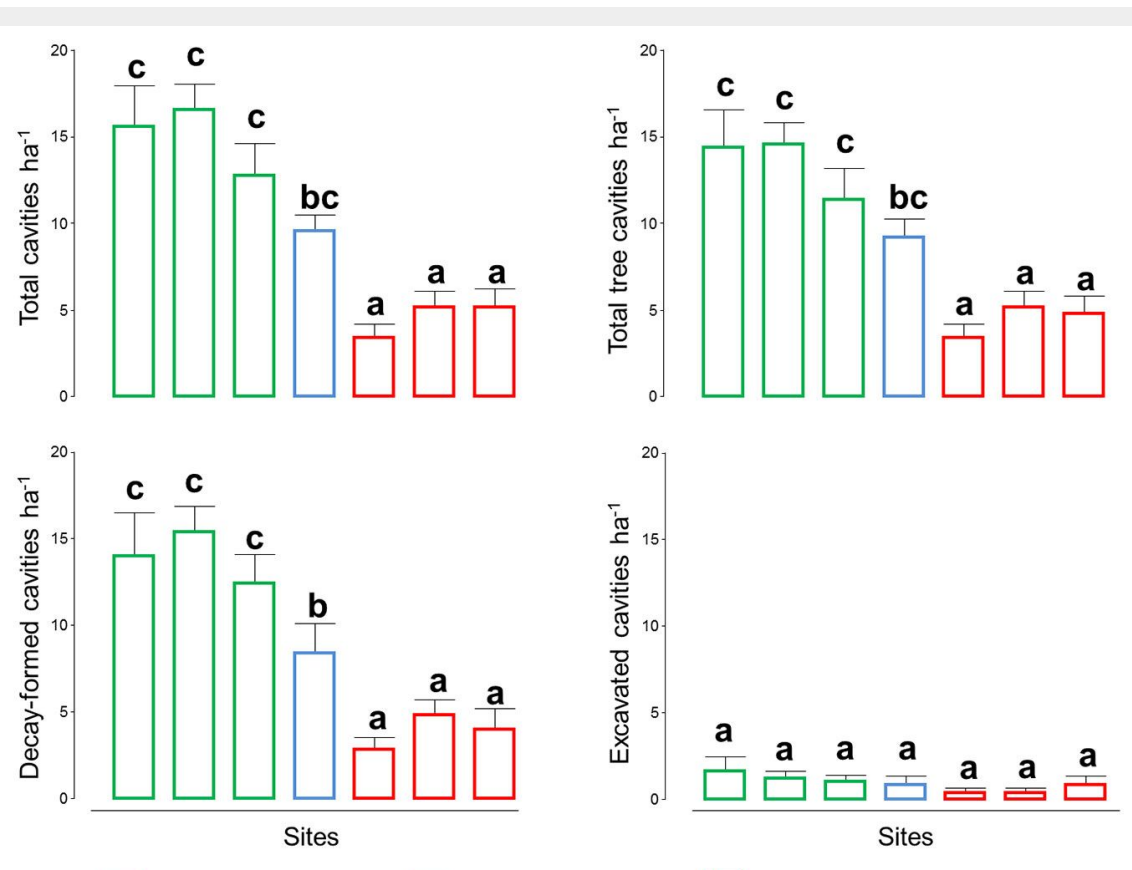

Control forest

Managed to FSC

Convencional logging forest

Fig. 2 - Density (mean $\pm \mathrm{SE}$ ) of the total cavities and total trees with cavities at the seven sites with different levels of logging in the piedmont forests of northwestern Argentina. The different letters show significant differences between sites (KruskalWallis test, with a $P<0.05$ ). Numeric values shown in Tab. S1 (Supplementary material).
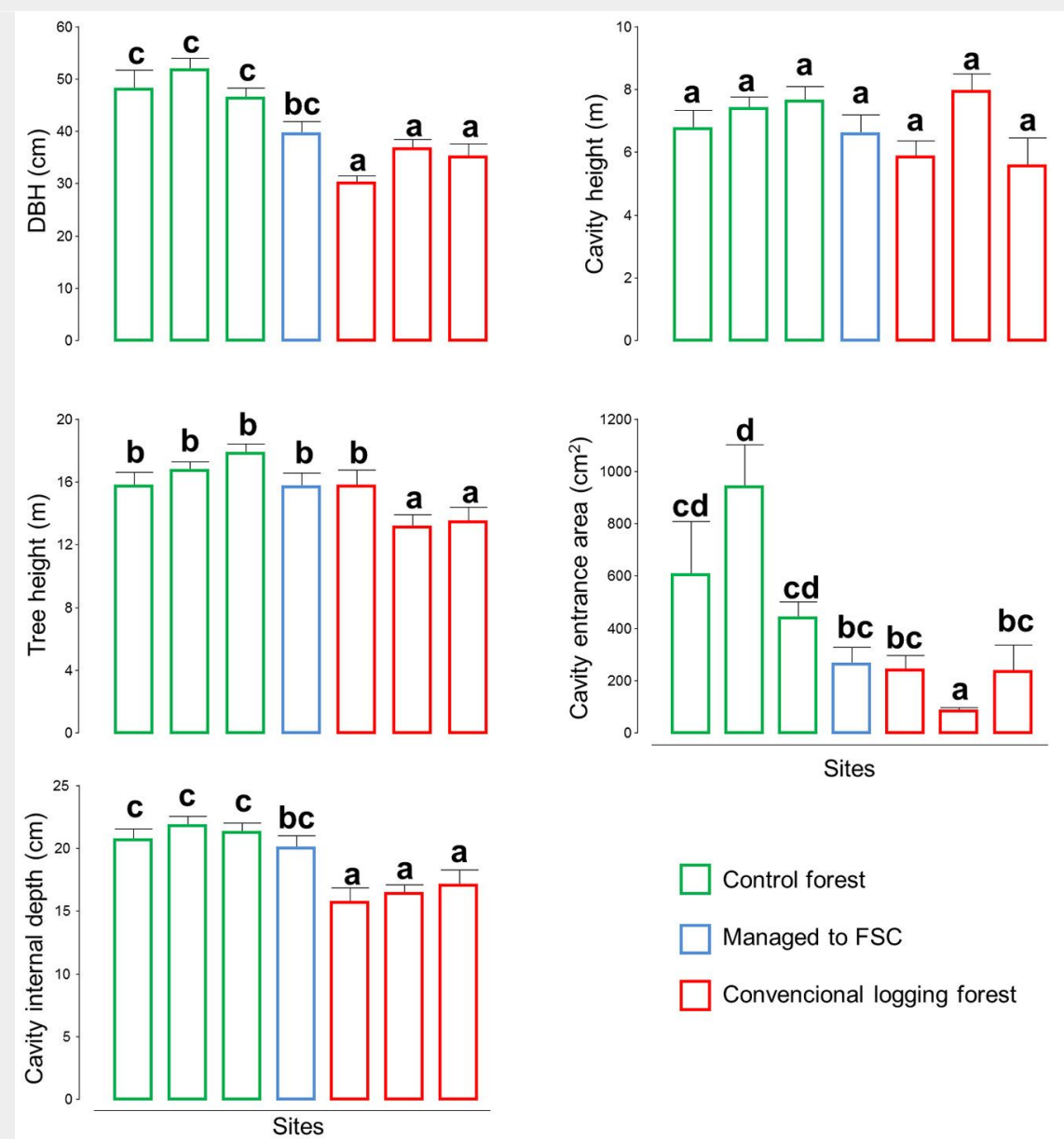

Control forest

Managed to FSC

Convencional logging forest

Fig. 3 - Comparison between the characteristics of trees with cavities at seven sites with different levels of logging in the piedmont forests of northwestern Argentina. Different letters show significant differences between sites (Kruskal-Wallis test, with a $P<0.05)$. Numeric values shown in Tab. S1 (Supplementary material). 


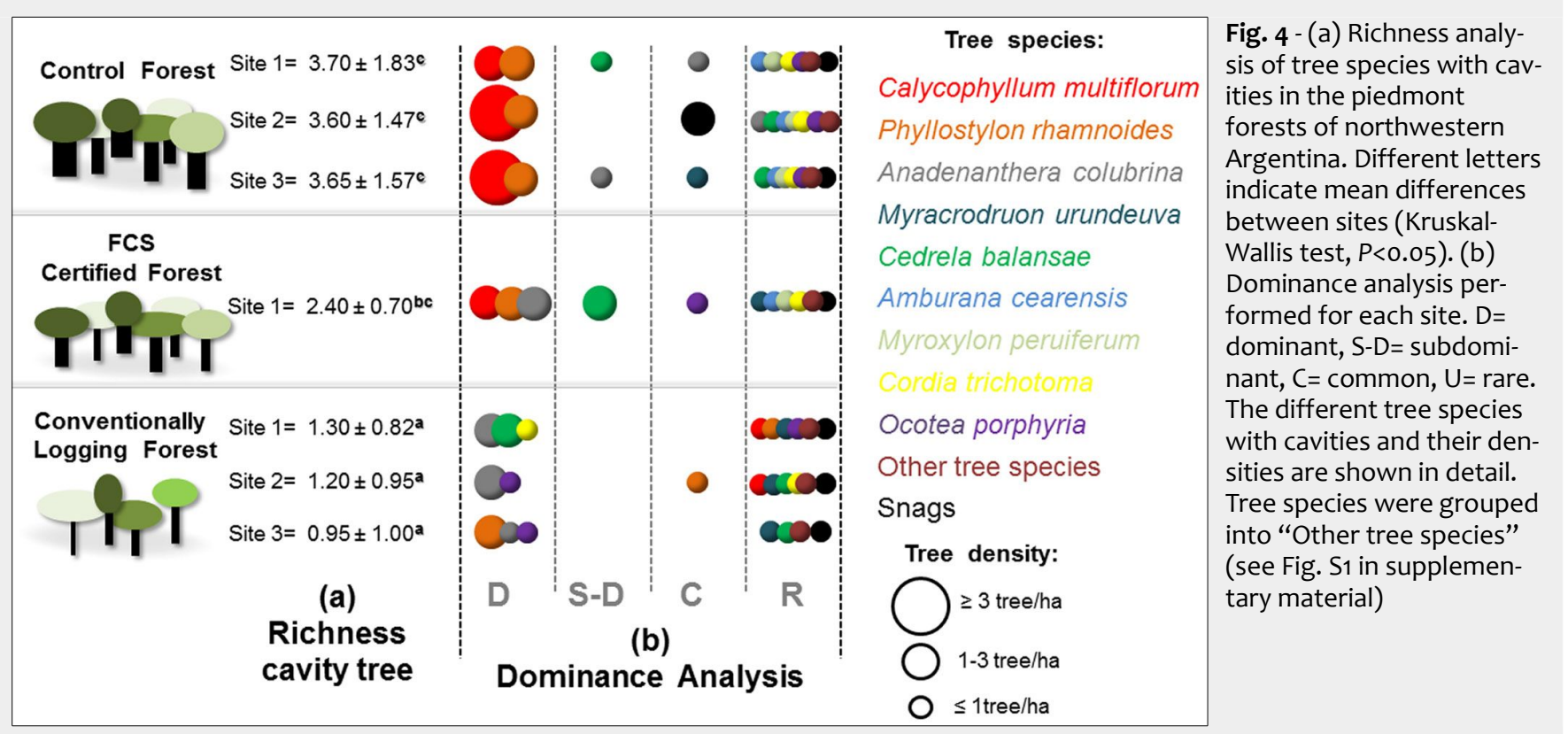

requirements for cavity-nesting birds (Politi et al. 2010, Schaaf et al. 2019).

In addition, a similar richness of cavity tree species was recorded at certified and control sites, including high-value timber species such as C. multiflorum, C. balansae, $M$. urundeuva, A. cearensis (currently classified as Endangered species by the IUCN), M. peruiferum, and Schinopsis lorentzii. These species were absent (e.g., A. cearensis, $M$. peruiferum and S. lorentzii) or with a lower density (C. multiflorum, C. balansae, $M$. urundeuva) in conventionally logged sites and this indicates that conventional management of the piedmont forests does not guarantee the presence of all cavity tree species. These tree species are extremely important for secondary cavitynesting birds (Ruggera et al. 2016), and A. cearensis, $M$. peruiferum, and S. lorentzii are particularly used by large secondary cavitynesting birds (Schaaf et al. 2019). These large birds, such as toucans, owls, vultures and other insectivorous birds play an important role in seed dispersal and pest control. Therefore, they play an important role in the persistence of the ecosystem services in the forest (Ruggera et al. 2016).

\section{Conclusion}

Despite the fact that more sites with forest certification are needed to fully understand richness, availability (density) and density of cavity trees, this study defines some key characteristics to assure the conservation of avian cavity-nesters. The cavity-nesting bird species inhabiting piedmont forests rely not only on certain tree species in particular but also on their characteristics (Politi et al. 2009, Ruggera et al. 2016, Schaaf et al. 2019). Sites with certified logging keep these specific characteristics (possibly due to reduced impact logging), such as tree size suitable for birds (e.g., DBH > $40 \mathrm{~cm}$ ). We can affirm that the certification standards implemented in piedmont forests may guarantee the richness and characteristics of key tree species for secondary cavity-nesting birds. This type of management preserves the tree species most used by secondary cavitynesting birds: C. multiflorum, C. balansae, A. cearensis, M. urundeuva and snags (Ruggera et al. 2016, Schaaf et al. 2019). These kinds of studies could be used to evaluate the impact of forest certification on specific animal groups, such as those evaluated in the present study (Gullison 2003, Rametsteiner \& Simula 2003), since the simple implementation of certification standards ensures biodiversity conservation. We suggest continuing with forests under certification (such as FSC) in order to conserve the high levels of biodiversity (Campos-Cerqueira et al. 2019), taking into account that tropical and subtropical forests around the world have high biodiversity and provide vital ecosystem services, which are being degraded by unregulated logging activities (Jennings et al. 2001, Van Kuijk et al. 2009, Arbainsyah et al. 2014).

\section{Acknowledgements}

We wish to thank field assistants that contributed with field work. This study was funded by Agencia Nacional de Promoción Científica y Tecnológica (PICT 2012-0892, Préstamo BID), CONICET (PIP 112-20120100259 CO), CIT-JUJUY (PIO 1402014100133), Rufford small grant, Optic for the tropic, Bergstrom Award, and Idea Wild. AAS is a post-doctoral fellow at CONICET, ET and CGV are doctoral fellows at CONICET, and RAR, NP and LR are researchers at CONICET.

\section{References}

Arbainsyah $\mathrm{H}$, De longh $\mathrm{H}$, Kustiawan $\mathrm{W}$, De Snoo GR (2014). Structure, composition and diversity of plant communities in FSC-certified, selectively logged forests of different ages compared to primary rainforest. Biodiversity and Conservation 23 (10): 2445-2472. - doi: 10.1007/s10531-014-0732-4

Arias M, Bianchi AR (1996). Estadisticas climatologicas de la provincia de Salta [Climatological statistics of the province of Salta]. EEA Salta, Direccion de Medio Ambiente y Recursos Naturales, Gobierno de Salta, Salta, Argentina. [in Spanish]

Auld G, Gulbrandsen LH, McDermott CL (2008). Certification schemes and the impacts on forests and forestry. Annual review of environment and resources 33: 187-211. - doi: 10.1146/an nurev.environ.33.013007.103754

Brown AD, Grau HR, Malizia LR, Grau A (2001). Argentina. In: "Bosques Nublados del Neotropico" (Kappelle M, Brown AD eds). InBio, Santo Domingo de Heredia, Costa Rica, pp. 623-659. [in Spanish]

Brown AD, Malizia LR (2004). Las selvas pedemontanas de las Yungas [The foothill forests of the Yungas]. Ciencis Hoy 14 (83): 52-63. [in Spanish]

Campos-Cerqueira M, Mena JL, Tejeda-Ggómez V, Aguilar-Amuchastegui N, Gutierrez N, Aide TM (2019). How does FSC forest certification affect the acoustically active fauna in Madre de Dios, Peru? Remote Sensing in Ecology and Conservation 9: 281. - doi: 10.1002/rse2.120

Cashore BW, Auld G, Newsom D (2004). Governing through markets: forest certification and the emergence of non-state authority. Yale University Press, New Haven, CT, USA, pp. 352.

Cockle K, Martin K, Wiebe KL (2008). Availability of cavities for nesting birds in the Atlantic Forest. Argentina. Ornitologia Neotropical 19: 269278.

Cockle KL, Martin K, Drever MC (2010). Supply of tree-holes limits nest density of cavity-nesting birds in primary and logged subtropical Atlantic forest. Biological Conservation 143 (11): 28512857. - doi: 10.1016/j.biocon.2010.08.002

Cornelius C, Cockle K, Politi N, Berkunsky I, Sandoval L, Ojeda V, Rivera L, Hunter MJr, Martin K (2008). Cavity-nesting birds in Neotropical forests: cavities as a potentially limiting resource. Ornitologia Neotropical 19: 253-268. 
[online] URL: http://hdl.handle.net/20.500.1211 o/paper_10754377_v19_nSUPPL_p253_Corneliu $\mathrm{s}$

Cubbage F, Diaz D, Yapura P, Dube F (2010). Impacts of forest management certification in Argentina and Chile. Forest Policy and Economics 12 (7): 497-504. - doi: 10.1016/j.forpol.2010.06.0 04

De Lima ACB, Keppe AN, Alves MC, Maule RF, Sparovek G (2008). Impact of FSC forest certification on agroextractive communities of the state of Acre, Brazil. Instituto de Manejo e Certificação Florestal e Agrícola (Imaflora). University of Sao Paulo (USP), Entropix Engineering Company, pp. 126. [online] URL: http://www. eco-index.org/search/pdfs/

Di Rienzo JA, Balzarini MG, González I, Tablada M, Guzmán W, Robledo CW, Casanoves F (2008). Software INFOSTAT Versión 2008. FCA, UNC, Córdoba, Argentina.

Elbakidze M, Angelstam P, Andersson K, Nordberg $M$, Pautov $Y$ (2011). How does forest certification contribute to boreal biodiversity conservation? Standards and outcomes in Sweden and NW Russia. Forest Ecology and Management 262 (11): 1983-1995. - doi: 10.1016/j.foreco. 2011.08.040

FAO (2006). Global forest resources assessment 2005 - Progress towards sustainable forest management. FAO Forestry Paper No. 147. Rome, Italy, pp. 315. [online] URL: http://www. fao.org/forestry/fra2005/en/

FSC (2015). FSC principles and criteria for forest stewardship. FSC-STD-01-001 V5-2 EN, Forest Stewardship Council, Bonn, Germany, pp. 32. Gullison RE (2003). Does forest certification conserve biodiversity? Oryx 37 (2): 153-165. - doi: 10.1017/S0030605303000346

Jennings SB, Brown ND, Bshier DH, Whitmore TC, Loves CA (2001). Ecology provides a pragmatic solution to the maintenance of genetic diversity in sustainably managed tropical rain forests. Forest Ecology and Managment 154: 110. - doi: 10.1016/S0378-1127(00)00637-X Johansson T, Hjältén J, De Jong J, Von Stedingk H (2013). Environmental considerations from legislation and certification in managed forest stands: a review of their importance for biodiversity. Forest Ecology and Management 303: 98-112. - doi: 10.1016/j.foreco.2013.04.012

Martin K, Eadie JM (1999). Nest webs: a community-wide approach to the management and conservation of cavity-nesting forest birds. Forest Ecology and Management 115 (2-3): 243-257. - doi: 10.1016/S0378-1127(98)00403-4

Miteva DA, Loucks CJ, Pattanayak SK (2015). Social and environmental impacts of forest management certification in Indonesia. PLoS One 10 (7): e0129675. - doi: 10.1371/journal.pone.012 9675

Nebel G, Quevedo L, Jacobsen JB, Helles F (2005). Development and economic significance of forest certification: the case of FSC in Bolivia. Forest Policy and Economics 7 (2): 175186. - doi: 10.1016/S1389-9341(03)00030-3

Newsom D, Hewitt D, Alliance R (2005). The global impacts of SmartWood certification. Alliance, New York, USA, pp. 39.

Pinzón J, Spence JR (2010). Bark-dwelling spider assemblages (Araneae) in the boreal forest: dominance, diversity, composition and life-histories. Journal of Insect Conservation 14 (5): 439-458. - doi: 10.1007/s10841-010-9273-7

Politi N, Hunter MJr, Rivera L (2009). Nest selection by cavity-nesting birds in subtropical montane forests of the Andes: implications for sustainable forest management. Biotropica 41 (3): 354-360. - doi: 10.1111/j.1744-7429.2008.00481.x Politi N, Hunter MJr, Rivera L (2010). Availability of cavities for avian cavity nesters in selectively logged subtropical montane forests of the Andes. Forest Ecology and Management 260 (5): 893-906. - doi: 10.1016/j.foreco.2010.06.009

Prado DE (2000). Seasonally dry forests of tropical South America: from forgotten ecosystems to a new phytogeographic unit. Edinburgh Journal of Botany 57 (3): 437-461.

Rametsteiner E, Simula M (2003). Forest certification - an instrument to promote sustainable forest management? Journal of Environmental Management 67 (1): 87-98. - doi: 10.1016/S03014797(02)00191-3

Ranius T, Kindvall O (2004). Modelling the amount of coarse woody debris produced by the new biodiversity-oriented silvicultural practices in Sweden. Biological Conservation 119 (1): 51-59. - doi: 10.1016/j.biocon.2003.10.021

Richardson DM, Bradford JW, Range PG, Christensen J (1999). A video probe system to inspect red-cockaded woodpecker cavities. Wildlife Society Bulletin 27 (2): 353-356. [online] URL: http://www.jstor.org/stable/3783901

Ruggera RA, Schaaf AA, Vivanco CG, Politi N, Rivera LO (2016). Exploring nest webs in more detail to improve forest management. Forest Ecology and Management 372: 93-100. - doi: 10.1016/j.foreco.2016.04.010

Schaaf AA, Ruggera RA, Tallei E, Vivanco CG, Rivera L, Politi N (2019). Identification of tree groups used by secondary cavity-nesting birds to simplify forest management in subtropical forests. Journal of Forestry Research 31 (4): 1417-1424. - doi: 10.1007/s11676-019-00918-9

SGAJ (2012). Bases para el manejo sostenible de los Bosques Nativos de Jujuy [Bases for the sustainable management of the native forests of Jujuy]. Secretaria de Gestión Ambiental de la Provincia de Jujuy - SGAJ, Fundación ProYungas. Incotedes, Gobierno de la Provincia de Jujuy, Jujuy, Argentina, pp. 206. [in Spanish]

Van Kuijk M, Putz FE, Zagt RJ (2009). Effect of forest certification on biodiversity. Tropenbos International, Wageningen, Netherlands, pp. 94.

Zawadzka D, Drozdowski S, Zawadzki G, Zawadzki J (2016). The availability of cavity trees along an age gradient in fresh pine forests. Silva Fennica 50 (3): 1441. - doi: 10.14214/sf.1441

\section{Supplementary Material}

Tab. S1 - Numerical values of the different variables measured at each site of the piedmont forest in northwestern Argentina.

Fig. S1 - Static graphs obtained from the Dominance analysis at each site of the piedmont forest in northwestern Argentina.

Link: Schaaf_3220@supplo01.pdf 